\title{
The Pietist Revival's Implications for Church Ministry in the Post-Pandemic Church ${ }^{1}$
}

\author{
Julian Edwin Pace IV1)* \\ 1) Th. D Student, Evangelical Seminary - Myerstown, United State \\ *) Correspondent author: julian.pace@evangelical.edu
}

Received: 14 February 2021/ Accepted: 28 March 2021/ Published: 04 April 2021

\begin{abstract}
This article contends that the Pietist revival of the seventeenth century provides a "usable past" that the contemporary church, currently reeling from the global Covid-19 pandemic, can learn from. It chronicles how the Pietist movement was born out of major disruption, rediscovered vital Biblical emphases and methods such as the common priesthood doctrine, the spiritual giftedness of all God's people, and small-group spiritual formation. Such emphases inspired many Pietists to improve the church's moral and spiritual life, ameliorate society's most pressing social problems, and evangelize their neighbors and new people groups. This article closes by exploring how Pietism's most vital emphases and methods might be appropriately applied in the post-pandemic church. The goal is that the post-pandemic church will emerge healthier and more vibrant than the contemporary and pre-pandemic church.
\end{abstract}

Keywords: church, pietist, Post-Pandemic, priesthood, spiritual

Abstrak

Artikel ini berpendapat bahwa kebangkitan Pietis abad ketujuh belas menyediakan "masa lalu berguna" yang dapat dipelajari oleh gereja kontemporer, yang saat ini sedang terhuyung-huyung dari pandemi Covid-19 global. Ini mencatat bagaimana gerakan Pietis lahir dari gangguan besar, menemukan kembali penekanan Alkitab yang penting dan metode seperti doktrin imamat umum, karunia spiritual dari semua umat Allah, dan formasi spiritual kelompok kecil. Penekanan seperti itu mengilhami banyak orang Pietis untuk meningkatkan kehidupan moral dan spiritual gereja, memperbaiki masalah sosial masyarakat yang paling mendesak, dan menginjili tetangga mereka dan kelompok orang baru. Artikel ini ditutup dengan mengeksplorasi bagaimana penekanan dan metode paling vital dari Pietisme dapat diterapkan

${ }^{1}$ The author defines the "Post-Pandemic Church" as the coming, and already emerging, church that will be profoundly shaped by its' experiences with the Covid-19 pandemic for the foreseeable future. See also Michael Adam Beck and Rosario Picardo, Fresh Expressions in a Digital Age: How the Church Can Prepare for a Post Pandemic World (Nashville, TN: Abingdon Press, 2021). 
dengan tepat di gereja pasca-pandemi. Semua itu bertujuan agar gereja pascapandemi muncul lebih sehat dan lebih bersemangat daripada gereja kontemporer dan pra-pandemi.

Kata-kata Kunci: gereja, pietis, pasca pandemi, imamat, spiritual

\section{Introduction}

Perhaps no adjective could better describe the year 2020 than disruptive. Almost every aspect of human life was somehow altered (in many cases fundamentally) by the global Covid-19 pandemic. Church ministry was hardly exempt from this widespread trend of disruption. Many local churches were forced to suspend large gatherings in their facilities and fundamentally retool the way they did ministry. ${ }^{2}$ While some may long for a swift return to pre-pandemic patterns of ministry, often typified by an almost exclusive, and sometimes even unhelpful, focus on large, highly programmed gatherings often directed by ordained ministers, such a reactionary strategy is potentially unwise. ${ }^{3}$

Can the church become more faithful and vibrant, instead of weaker and more wayward, due to its' experiences with the Covid-19 pandemic? Could the global pandemic be an opportunity to move away from unhelpful ministry practices and paradigms into a more vibrant and spirit-filled future? This article will seek to offer some answers to these pressing questions. It is the author's contention that while disruptions like the Covid-19 pandemic are by their very nature painful, they also provide opportunities to leave behind unprofitable ways of doing ministry and rediscover fresher and more faithful ministry models. If the pre-pandemic church often thought of ministry as the almost exclusive domain of ordained ministers, the church must now envision a more critical role for the laity in church ministry if it wishes to emerge from the Covid-19 crises more vibrant. Fortunately for us, the seventeenthcentury renewal movement known as Pietism provides a helpful example of a movement that was born out of disruption, moved past stifling "clericalism" by reviving the doctrine of the common priesthood, and

\footnotetext{
2 Beck and Picardo, 9-12, 42.

${ }^{3}$ Ibid., 9-10.
} 
embraced spirit-filled lay-ministry once more. ${ }^{4}$ The contemporary church will be in need of such a renewal as we look towards a postpandemic future. ${ }^{5}$ We would be wise to learn from the Pietists who in some important ways successfully brought renewal to the church of their day.

\section{Method}

The author is convinced that Pietism (a movement and ethos that substantially shaped contemporary global Evangelicalism) provides a "usable past" that the contemporary church can learn from. ${ }^{6}$ As such, this paper will carefully document the thought and contributions of leading Pietists such as Phillip Jacob Spener (1635-1705), Johanna Eleonora Petersen (1644-1724), August Hermann Franke (1663-1727), and Karl Hildebrand Baron von Canstein (1667-1719). Careful consideration will be given to how they helped revive the concepts of the common priesthood doctrine and spirit-empowered lay-ministry in the Pietist movement. The fruitful results that emerged from such emphases will be explored as well. Finally, this article will briefly explore how the best insights of the Pietists might be applied in the post-pandemic church. The author is hopeful that the contemporary church will learn from the example of the Pietists and self-consciously appropriate their most valuable emphases and methods appropriately. All with the goal that the post-pandemic Church will in turn see a revival of lay-driven ministry and experience broad renewal.

\section{Result and Discussion}

\section{The Common Priesthood Doctrine and Spiritual Giftedness in German Pietism}

Pietism in its German context was born out of a climate of major disruption on the European continent. While we currently find ourselves

${ }^{4}$ See Denise D. Kettering-Lane, "Phillip Spener and the Role of Women in the Church: The Spiritual Priesthood of All Believers in German Pietism," Covenant Quarterly 75, no. 1 (2017): 50-69. https://covquarterly.com/index.php/CQ/article/view/64/63.

${ }^{5}$ Beck and Picardo, 42.

${ }^{6}$ Christopher Gehrz, "Does Pietism Provide a "Usable Past" for Christian Colleges and Universities," in The Pietist Vision of Christian Higher Education: Forming Whole and Holy Persons, ed. Christopher Gehrz (Downers Grove, IL: IVP Academic, 2015), 19-32. 
wrestling with the challenges associated with a global pandemic, the earliest German Pietists wrestled not only with the catastrophic results of the Thirty Years' War (1618-1648) but an accompanying plague as well. ${ }^{7}$ The Thirty Years' War was one of the most devastating conflicts that Europe had ever seen. Germany was affected more so than any other nation losing roughly one-third of its' population due to the conflict and the accompanying plague. ${ }^{8}$

No aspect of German life was left untouched by the conflict. Germany's economic, social, moral, and political life were all in shambles. Only exacerbating matters, the Lutheran Church enjoyed less prestige and influence than ever before and was largely unable to ameliorate the many problems that Germany faced. ${ }^{9}$ Affected by numerous weaknesses, the Lutheran Church was consistently unable to be a vibrant witness to the larger culture. Spiritual health at all levels of society was at a strikingly low ebb with drunkenness, debauchery, and various other sins common amongst even professing Christians. Some Lutherans during this period were convinced that occasional church attendance and passive participation in the sacrament of communion were sufficient grounds for salvation and a right standing with God. ${ }^{10}$

The Lutheran clergy were hardly immune themselves from these problems. While most Lutheran pastors during this time were very well educated, their lifestyles were often little better than the laity's. Furthermore, the preaching of many Lutheran pastors during this era was dry, academic, and frequently ineffective. Lutheran pastors often spent an inordinate amount of time preaching on doctrinal matters of very marginal importance and sermons often had precious little practical import. ${ }^{11}$ The Lutheran Church that emerged from Thirty Years' War was in desperate need of renewal.

Few Lutheran pastors during this period grasped the church's need of renewal more than Phillip Jacob Spener. Matriculating from the University of Strasbourg with his doctorate in 1664, he was assigned to a

${ }^{7}$ Douglas H. Shantz, An Introduction to German Pietism: Protestant Renewal at the Dawn of Modern Europe (Baltimore, MD: The Johns Hopkins University Press, 2013), 43.

${ }^{8}$ Ibid., 43.

${ }^{9}$ Ibid., 45-47.

${ }^{10}$ K. James Stein, Phillip Jakob Spener: Pietist Patriarch (Chicago, IL: Covenant Press, 1986), 21-22.

${ }^{11}$ Roger E. Olson and Christian T. Collins Winn, Reclaiming Pietism: Retrieving an Evangelical Tradition (Grand Rapids, MI: Eerdmans, 2015), 47. 
pastoral position in Frankfurt, Germany. Here he experienced firsthand the widespread malaise of the Lutheran Church. Desirous of correcting the errors of the church, Spener published a short book entitled Pia Desideria or "Heartfelt Desire for a God-pleasing Reform" which provided an outline for renewing the Lutheran Church. Few texts better represent the ethos of Pietism than the Pia Desideria and its' seminal place in the history of Pietism has led many scholars to dub Spener the "Patriarch" or "Father" of Pietism. 12

The first half of Spener's Pia Desideria is a critique of the morally and spiritually moribund Lutheran Church of his day. In it Spener critiques both the laity and the clergy for their lack of sincere piety. ${ }^{13}$ Spener takes up a far more constructive tone in the latter half of the work and gives instructions on how the spiritual and moral life of the Lutheran Church might be improved. For Spener, one way the church might experience renewal is by the clergy and the laity seeing church ministry as a cooperative endeavor rather than the sole purview of the clergy. ${ }^{14}$

As far as Spener was concerned, the Lutheran Church of his day was hobbled by a very stifling "clericalism." According to him, such clericalism was in part a very unhelpful holdover from medieval Roman Catholicism. ${ }^{15}$ A rediscovery and revival of lay ministry would be needed if the church were to be renewed. However, Spener understood that the laity needed an "empowering theology" that affirmed their place and utility in the Church if they were to ever engage in the ministries of the Church in a serious and sustained way. ${ }^{16}$ Spener found such an empowering theology in the common priesthood doctrine.

In the Pia Desideria, Spener draws upon scripture (1 Peter 2:9) and the thought of Martin Luther when he calls for a revival of the common priesthood doctrine. Following Luther closely, Spener notes that all Christians are members of the common priesthood and are therefore

${ }^{12}$ See Stein, 21-22.

${ }^{13}$ Phillip Jacob Spener, Pia Desideria, trans. Theodore G. Tappert (Minneapolis, MN: Fortress Press, 1964), 44-75.

${ }^{14}$ Ibid., 92-95.

${ }^{15}$ Ibid.

${ }^{16}$ Kettering-Lane, 53-61. 
capable of performing "priestly/spiritual" acts and ministering on behalf of God and the church. ${ }^{17}$

Spener would expand upon Luther's conception of the common priesthood in a later book called The Spiritual Priesthood and argue that all Christians could perform numerous ministerial functions on behalf of the Church. All Christians could pray for one another, comfort the sick and discouraged and read the scriptures for themselves. Furthermore, they could even teach the scriptures to their friends and neighbors provided they rightly understood them. ${ }^{18}$

While such suggestions appear tame by contemporary standards, Spener's recommendation that the laity could read the scriptures for themselves and even teach them was quite progressive for its day. While Luther dreamed of widespread Biblical engagement amongst the German people, such a dream would not come to fruition during his lifetime. By Spener's day, most Lutheran pastors were far more concerned with convincing the laity to read the catechism rather than the scriptures themselves. ${ }^{19}$

While Spener valued Luther's catechism and suggested that his parishioners read it, he was far more concerned with the laity engaging with the Biblical text itself. Indeed, a key element of his renewal program as outlined in the Pia Desideria was greater engagement with scripture by the clergy and the laity alike. Spener's quote from the Pia Desideria that "thought should be given to a more extensive use of the Word of God among us"20 makes this clear. Greater emphasis on scriptural engagement, combined with the empowering theology of the common priesthood doctrine, lead to an explosion of lay Bible-reading throughout Germany. As Spener had also suggested in the Pia Desideria, ${ }^{21}$ German Pietists quickly began to organize themselves into "conventicles" or "small groups" to study the scriptures together. ${ }^{22}$ Luther's earlier vision of the German people engaging with scripture on a mass level was beginning to take place.

\footnotetext{
${ }^{17}$ Spener, 92-95.

${ }^{18}$ Kettering-Lane, 58-59.

${ }^{19}$ Shantz, 204-205.

${ }^{20}$ Spener, 87.

${ }^{21}$ Ibid., 87-92.

${ }^{22}$ See Harry Yeide Jr, Studies in Classical Pietism: The Flowering of the Ecclesiola (New York, NY: Peter Lang Publishing, 1997).
} 
Fearing that conventicles could become breeding grounds for heresy, Spener initially preferred that clergy lead and supervise these meetings. ${ }^{23}$ However, he soon found such a restriction impractical and increasingly conventicle meetings were being led by the laity, including many very remarkable female Pietists. ${ }^{24}$

One such conventicle leader was a remarkable woman named Johanna Eleonora Petersen. Born into a noble (but poor) family, Petersen eventually became a close friend of Spener while they were both living in Frankfurt. Empowered by the common priesthood doctrine and inspired by Spener's call to the German people to reengage with scripture, Petersen taught herself Greek and Hebrew, in time becoming a very competent exegete. She eventually wrote more than a dozen books on theological and devotional topics. ${ }^{25}$ Remarkably, Petersen accomplished all of this while serving as a pastor's wife, raising several children, and managing a busy household.

One of Petersen's most important contributions to the Pietist movement was building on Spener's common priesthood emphasis. Through her writings, Petersen would add a "pneumatological" element to Pietism's renewed emphasis on lay ministry. If Spener had emphasized that lay-Christians were "authorized" to do ministry in virtue of their membership in the common priesthood, Petersen emphasized that layChristians were "equipped" and "gifted" to do ministry because of the indwelling of the Holy Spirit in their lives.

While Petersen's writings were warmly received by many Pietists, they were harshly criticized by some of the Lutheran clergy who found the idea of a woman writing theological literature scandalous and unacceptable. ${ }^{26}$ Furthermore, many were also uncomfortable with her work as a Bible teacher in conventicles. In response to such criticisms of her ministry, Petersen argued that the Holy Spirit could sovereignly enable whomever he wished to proclaim the scriptures and do ministry on behalf of the church. ${ }^{27}$

${ }^{23}$ Spener, 89-90.

${ }^{24}$ Kettering-Lane, 66.

25 Ruth Albrecht, "Johanna Eleonora Petersen in the Context of Women's and Gender Studies," in Pietism in Germany and North America 1680-1820, ed. Jonathan Strom, Hartmut Lehmann, and James Van Horn Melton (New York, NY: Routledge, 2018), 73.

${ }^{26}$ Martin Jung, "Johanna Eleonora Petersen," in The Pietist Theologians, ed. Carter Lindberg (Hoboken, NJ: Blackwell Publishing, 2005), 158-159.

${ }_{27}$ Albrecht, 74. 
Lest we understand Petersen anachronistically, it should be noted that she was no advocate of women's ordination and she believed that her primary place was in the domestic sphere. ${ }^{28}$ However, she was equally convinced that the Holy Spirit had gifted every Christian, whether male or female, clergy or lay, to do meaningful ministry on behalf of the church. Though married to a Lutheran cleric, there is little hint of clericalism in her theology of church ministry.

Petersen would rely heavily on passages of scripture like 1 Corinthians 12:7, Joel 2:28, and Acts 2:17-18 that speak of God endowing all his children with spiritual gifts to defend her calling to ministry. A response given to critics of her ministry is worth quoting at length.

Some will reproach me with Paul's words (1 Cor. 14:34 and 1 Tim. 2:12) that a woman should not teach in God's community. But they should know that these words do not pertain to me. I respect what the Holy Ghost has said through Paul and with reference to a woman's dutiful submission and I do not claim to teach in God's community. But this I know very well: that just as for Christ's grace and spirit there is no difference between man or woman (Gal. 3:28) God's grace cannot be dampened nor be suppressed by a woman, according to Paul's admonishment (1 Thess. 5:19). Rather, all spiritual gifts whether they appear in a man or a woman are worthy to be presented and applied to the common good (1 Cor. 12:7). Therefore, the Holy Ghost has given witness (through Joel 2:28 and Acts 2:17-18) that not only the sons but also the daughters of Israel may prophesy and that the Lord will pour out his Spirit not only over his male but also over his female servants. And Paul himself who has forbidden women to teach in the community attributes the gift of prophecy to both, men and women, in that very Epistle (1 Cor. 11:4-5). Since the Lord in his grace has given me the gift of such illumination from his spirit. I do know my humble place in the community, but I do also know that I have received the Lord's gift not in order to hide it but in order to make the most of it, to apply it for his honor and to the benefit of my neighbor. ${ }^{29}$

Several points from Petersen's response to her critics are notable. 1) Petersen accepted the almost universal view of her time that 1 Timothy 2

${ }^{28}$ Albrecht, 74-78.

${ }^{29}$ Johanna Eleonora Petersen, The Life of Lady Johanna Eleonora Petersen, Written by Herself, trans. Barbara Becker-Cantarino (Chicago, IL: University of Chicago Press, 2005), 26-28. 
and 1 Corinthians 14 forbade her from performing certain "public" ministries in the Lutheran Church. Petersen was no champion for women's ordination and held to rather traditional assumptions about the place of women in church, society, and culture. ${ }^{30}$ 2) However, Petersen also notes that the Holy Spirit has gifted both men and women to minister on behalf of the Church as spiritual gifts are given irrespective of gender. 3) If gifts are given irrespective of gender, then the role of prophet is open to both men and women. Thus, if she (Petersen) functions in the church as a prophet, and not as a teacher, she does not violate scripture passages such as 1 Timothy 2 and 1 Corinthians 14. Rather, she is merely living out the calling and gifting that God has sovereignly placed upon her life.

\section{Exploring the Accomplishments of German Pietism}

Spener's renewed emphasis on the common priesthood of all believers, combined with Petersen's emphasis on the spiritual giftedness of all Christians, proved to be a very potent combination. We have already noted that such emphases gave many lay Pietists the confidence they needed to engage with scripture on a much deeper level than ever before. This renewed interest in scripture manifested itself most notably in the formation of conventicles throughout Germany. ${ }^{31}$ Conventicles fostered an environment whereby scripture study could take place "communally" and provided an outlet where many lay Pietists could explore their capacities for pastoral and teaching ministries.

In conventicles, lay Pietists studied and taught scripture to one another, frequently encouraging their co-religionists to foster within their own lives a "heartfelt" and "living faith." 32 They also studied certain devotional texts in conventicles. A favorite was Johann Arndt's (15551621) True Christianity which insisted that genuine Christian faith is more than mere adherence to traditional Christian doctrine, it is also a call to radical discipleship and sanctification.

With their spiritual "temperature" increasing, many Pietists began to seek ways in which they could express their faith in public, concrete, and meaningful ways. Pietism could not exist solely to gather; it had to

\footnotetext{
${ }^{30}$ Petersen, 13.

${ }^{31}$ See Harry Yeide Jr, Studies in Classical Pietism: The Flowering of the Ecclesiola (New York, NY: Peter Lang Publishing, 1997).

32 Shantz, 284.
} 
gather and go. Thus, Pietists became increasingly interested in healing the social ills caused by the Thirty Years' War, sharing the Gospel with their neighbors, and engaging in mission work with new people groups Europeans were only just beginning to understand. ${ }^{33}$ Such tasks would only be accomplished through consistent lay engagement and sacrifice.

Perhaps no group of Pietists took these concerns more seriously than the Pietists of Halle, Germany. The Halle Pietist wing was led by the capable pastor and professor August Hermann Franke (1663-1727). Under his leadership, the Halle Pietists founded a university, an orphanage, a Bible institute, and many other charitable efforts. ${ }^{34}$ Such endeavors only succeeded due to the generous gifts and sacrifices of many lay Pietists, including the very remarkable and pious nobleman Karl Hildebrand Baron von Canstein. ${ }^{35}$

Von Canstein enjoyed a varied career serving as a lawyer, soldier, and important lay Pietist leader at different periods during his life. In 1690 he fell ill with a severe case of dysentery that very nearly took his life. On what was very nearly his deathbed he prayed "Dear Father in heaven, if you save me from this illness, I will serve you my life long." ${ }^{36}$ Never forgetting his vow, he committed himself wholeheartedly to God's service whilst never becoming an ordained minister. Notably, von Canstein would contribute not only financially to the Pietist cause. He eventually became a close friend and confidant of Francke's, consulting with him on almost every ministry endeavor that the Halle Pietists undertook. ${ }^{37}$

Convinced that scriptural engagement was key to widespread spiritual renewal in Germany, Francke and von Canstein established a Bible institute in Halle. The institute's principal mission was to make Bibles, devotional texts, and tracts available to anyone in Europe who desired them. For the Pietists, poverty ought never be a barrier to someone reading the Bible and discovering the Gospel within its pages. Thus, the Bibles, devotional texts, and tracts produced by the Bible

\footnotetext{
33 Shantz, 283-285.

${ }^{34}$ Olson and Winn, 5l-60.

${ }^{35}$ Ibid., 56.

${ }^{36}$ Gary R. Sattler, God's Glory, Neighbor's Good (Chicago, IL: Covenant Press, 1982),

${ }^{37}$ Ibid.
} 59-60. 
institute were provided to all at little to no charge. ${ }^{38}$ It has been estimated that during the eighteenth century the Halle Pietists produced more than three million copies of the Bible. ${ }^{39}$

The Bible institute benefitted tremendously from the vision and support of von Canstein. However, sharing the Bible with Europeans was not enough for him. He dreamed of a day when the Bible would be available in every language, "so that the precious Word of God may be brought among all nations." 40 Von Canstein would live to see his vision of sharing the Bible with "all nations" partially fulfilled when Pietist missionaries sent out from Halle became some of the first Protestant missionaries to visit India in $1705 .{ }^{41}$ It should be noted that during this time period the task of translation was arduous, and printing remained fairly expensive. Without the sustaining vision and financial support of von Canstein, the Bible institute would have likely floundered. Considering how much he contributed the Pietist cause, it is little wonder that Francke called his old friend von Canstein "indispensable." 42

The Halle Pietists also demonstrated profound concern for the urban poor, particularly orphans. Germany was burdened by many orphans due to the horrors of the Thirty Years War and the accompanying plague. Both the state and the church had previously proven ineffective in ameliorating Germany's massive social ills. ${ }^{43}$ In response to Germany's widespread orphan problem, the Halle Pietists founded a school for poor children as well as an orphanage. The orphanage quickly became known throughout Europe for providing orphans with a strong education (including instruction in the Bible and theology) and excellent living conditions. ${ }^{44}$ Eventually, Halle's notable orphanage inspired the opening of other orphanages throughout Europe. Indeed, it has been estimated that twenty-five percent of all orphanages established in German lands between 1695 and 1802 were inspired by and modeled after the Halle orphanage. ${ }^{45}$

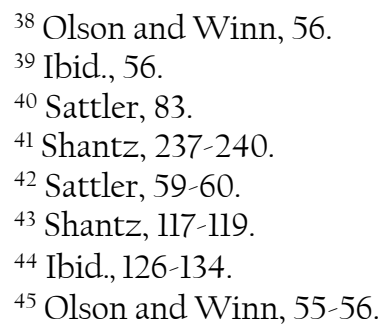


Again, we must note that Halle's poor school and orphanage would not have succeeded without very extensive lay involvement. The poor school was founded largely due to the very generous support of a laymen named Georg Rudolph von Schweinitz who was another close friend of Francke's. Furthermore, Halle's poor school and orphanage were staffed by an innumerable number of obscure lay Pietists who served as instructors, physicians, cooks, and maintenance staff. ${ }^{46}$ Spurred by a theology that emphasized every Christian's ability and giftedness to minister of behalf of God and the Church, lay Pietists did not limit their forays in ministry to the already initiated in the conventicle, rather they ministered to some of the most vulnerable and forgotten people of society: the urban poor and orphans.

To be sure, the Pietists' renewed emphasis on lay-driven ministry probably contributed to certain negative outcomes in the movement as well. While Spener dreamed that conventicles would be a decisive force for renewal within the larger Church, many conventicle leaders and participants preferred conventicle life to what they generally experienced in the larger Church. Some eventually became separatist and sectarian. With conventicles often being directed by charismatic (but theologically unsophisticated) laypeople, it did not take long for a "radical" wing to develop within Pietism. This radical wing often being distinguished by its penchant for heterodoxy and separatism. ${ }^{47}$

Even Johanna Eleonora Petersen, with her helpful and empowering emphasis on the spiritual giftedness of all of God's people, became interested in "universalism" much to her old friend Spener's dismay. ${ }^{48}$ To be sure, many contemporary Evangelical Protestants will resonate with Spener's concerns. All movements will necessarily have their flaws and shortcomings and Pietism is no exception. Nevertheles, contemporary Evangelical Protestants can find much to celebrate about Pietism's legacy.

\section{Pietism and the Post-Pandemic Church}

Does Pietism provide a "usable past" that the contemporary church might learn from? How might the contemporary church apply the Pietists' most helpful emphases and methods so that post-pandemic

\footnotetext{
${ }^{46}$ Shantz, 127-134.

47 Ibid., 147.

${ }^{48}$ Jung, 148-155.
} 
church emerges more faithful and vibrant than the church that came before it? First, the contemporary church must come to grips with the fact that the post-pandemic church, particularly in its North American and European contexts, will be a church that is profoundly in need of renewal. Church health researcher Thom Rainer has estimated that "the median decline of churches once in the post-pandemic phase will be around 20 percent." 49 While widespread government-mandated lockdowns have necessitated some level of disconnectedness in the church, and some members (particularly the elderly) remain largely disconnected due to health concerns, many Christians have exited the church altogether during the pandemic. The contemporary church must forthrightly recognize that inadequate spiritual formation has produced very many nominal Christians. We must do better in the future. Fortunately, the Pietist revival provides an outline for how a spiritually and morally moribund Church can experience vibrancy even after major disruptions occur.

With church decline only accelerating throughout much of the Western world, the necessity of reengaging the laity in the task of church renewal is quite clear. However, without a biblically grounded and empowering theology of lay ministry, such a possibility may never become a reality. ${ }^{50}$ Thus, we would do well to learn from Spener's emphasis on the common priesthood doctrine as well as Petersen's emphasis on the spiritual giftedness of all Christians.

Second, the contemporary church would also be wise to emphasize, just as Spener did, that the ministry of the church is the cooperative endeavor of the clergy and the laity. For Spener, ordained clergy are uniquely called to the important task of maintaining theological orthodoxy and biblical faithfulness in the church. ${ }^{51}$ We must continue to affirm that ordained pastoral ministry "is a gift of God to the church. ${ }^{52}$ However, we must also affirm that the laity play a vital and

${ }^{49}$ Thom S. Rainer, "Five Ways the Post-Place Church Will Look Different after Covid," Church Answers Blog, February, 26, 2021,

https://churchanswers.com/blog/five-ways-the-post-place-church-will-look-differentafter-covid/.

${ }^{50}$ Veli-Matti Kärkkäinen, An Introduction to Ecclesiology (Downers Grove, IL: IVP Academic, 2002), 65-66.

${ }^{51}$ Stein, 151.

52 William H. Willimon, Pastor: The Theology and Practice of Ordained Ministry

(Nashville, TN: Abingdon Press, 2002), 12. 
indispensable role in the ministry of the church as well. Without consistent lay engagement the church will cease to be effective.

Third, it is not an accident that the author has provided examples of clergy and lay Pietists pursuing ministry in a cooperative and complementary manner, rather than in a spirit of competitiveness and suspicion of one another. While as a clergyman, Spener's emphasis on the common priesthood was essential to Pietism's vitality, as a layperson, Petersen considerably fleshed out Spener's conception of the common priesthood doctrine by adding a pneumatological element to it and emphasizing the spiritual giftedness of all God's people. Furthermore, as a clergyman, Francke was the primary architect behind the institutions and accomplishments of Halle Pietism. However, he described von Canstein, a layman, as "indispensable" and essential to Halle Pietism's success.

Finally, the contemporary church would be wise to learn from the Pietist practice of conventicles, in small groups, Pietists could engage with scripture on a deeper level than they ever could in much larger gatherings. Furthermore, within conventicles robust and intimate spiritual formation could take place. Authorized and empowered by Spener and Petersen's emphasis on lay ministry and spiritually formed by serious and sustained engagement with the Biblical text, Pietists became increasingly interested in alleviating Germany's most debilitating social ills, sharing God's word with their neighbors, and taking the Gospel to new people groups. The Pietists quite rightly understood that before their movement could grow numerically larger it had to grow spiritually deeper.

As the contemporary church begins to craft what the postpandemic church will look like, we would be wise to emulate the Pietists' emphasis on small-group spiritual formation. Large gatherings will not be feasible in many parts of the world for some time. Thus, the conventicle model may be attractive to Christians who live in parts of the world that emerge from the pandemic more slowly. Furthermore, even when large gatherings become more feasible, we would be unwise to return to older patterns of ministry that often-placed undue emphasis on large, highly programmed gatherings driven almost exclusively by the clergy. Indeed, scholar-practitioners Michael Adam Beck and Rosario Picardo have noted in their research that these sorts of gatherings may already be losing their evangelistic effectiveness as younger generations 
increasingly find the "polished corporate nature of the show" inauthentic and unappealing. ${ }^{53}$ Rather than focusing almost solely on "drawing a large crowd," we should focus more on "forming whole and holy persons." ${ }^{54}$ Before the post-pandemic church grows numerically larger it must grow spiritually deeper.

\section{Conclusion}

In conclusion, Pietism does provide a "usable past" that can help the post-pandemic church be more faithful and vibrant than the church that came before it. By empowering the laity and focusing on smallgroup spiritual formation, the Pietists created a movement that positively impacted their culture and brought renewal to church of their day. By assessing what is most praiseworthy about the Pietist movement and by applying its' emphases and insights carefully in our contemporary ministry context, the post-pandemic church may yet be far healthier and more vibrant than the pre-pandemic church.

While still mired in the pandemic, and as the church looks towards a post-pandemic future, we should reprioritize and reemphasize important biblical doctrines such as the common priesthood and the spiritual giftedness of all Christians. Ministry must be the cooperative endeavor of the clergy and the laity once more. Just as Francke saw von Canstein as "indispensable" to the Halle Pietist mission, the clergy of today must make more room for the laity in the planning, preparation, and execution of church ministry. With a stronger presence of empowered "lay-ministers," church services will likely be less streamlined and produced, but they will likely be more authentic as well, Furthermore, they will more fully display the beauty and diversity of the whole body of Christ. ${ }^{55}$

Finally, clergy must mentor and develop mature Christian laypeople who can lead small-group Bible studies effectively and share in the critical task of spiritual formation. Lay Bible study leaders, such as Petersen, were essential to Pietism's spiritual vitality and success. The

\footnotetext{
${ }^{53}$ Beck and Picardo, 9-10.

${ }^{54}$ Katherine J. Nevins, "Calling for Pietist Community: Pia Desideria in the Classroom," in The Pietist Vision of Christian Higher Education: Forming Whole and Holy Persons, ed. Christopher Gehrz (Downers Grove, IL: IVP Academic, 2015), 52-54.

55 Beck and Picardo, 9.
} 
church would be wise to learn from the Pietist's emphasis on small group spiritual formation and avoid creating another generation of very nominal Christians. Once more, the church will only grow numerically larger when it first grows spiritual deeper. To be sure, a more dedicated and spiritually mature body of Christians will be better prepared to share the Gospel outside the church and engage the larger culture in a positive way. By wisely applying what was best about the Pietist movement to our contemporary ministry context, we can look to the church's future with confidence and expectation.

\section{Bibliography}

Albrecht, Ruth. "Johanna Eleonora Petersen in the Context of Women's and Gender Studies." in Pietism in Germany and North America 16801820, ed. Jonathan Strom, Hartmut Lehmann, and James Van Horn Melton, 71-84. New York, NY: Routledge, 2018.

Beck, Michael Adam and Rosario Picardo. Fresh Expressions in a Digital Age. Nashville, TN: Abingdon Press, 2021.

Gehrz, Christopher. "Does Pietism Provide a "Usable Past" for Christian Colleges and Universities," in The Pietist Vision of Christian Higher Education: Forming Whole and Holy Persons, edited by Christopher Gehrz, 19-32. Downers Grove, IL: IVP Academic, 2015.

Jung, Martin. "Johanna Eleonora Petersen." in The Pietist Theologians, edited by Carter Lindberg, 147-160. Hoboken, NJ: Blackwell Publishing, 2005.

Kärkkäinen, Veli-Matti. An Introduction to Ecclesiology. Downers Grove, IL: IVP Academic, 2002.

Kettering-Lane, Denise D. "Phillip Spener and the Role of Women in the Church: The Spiritual Priesthood of All Believers in German Pietism." Covenant Quarterly 75, no. 1 (2017): 50-69. https://covquarterly.com/index.php/CQ/article/view/64/63.

Nevins, Katherine J. "Calling for Pietist Community: Pia Desideria in the Classroom," in The Pietist Vision of Christian Higher Education: Forming Whole and Holy Persons, ed. Christopher Gehrz, 52-66. Downers Grove, IL: IVP Academic, 2015.

Olson, Roger E. and Christian T. Collins Winn. Reclaiming Pietism: Retrieving an Evangelical Tradition. Grand Rapids, MI: Eerdmans, 2015.

Petersen, Johanna Eleonora. The Life of Lady Johanna Eleonora Petersen, Written by Herself, translated by Barbara Becker-Cantarino. Chicago, IL: University of Chicago Press, 2005. 
Rainer, Thom S. "Five Ways the Post-Place Church Will Look Different after Covid." Church Answers Blog, February, 26, 2021. https://churchanswers.com/blog/five-ways-the-post-place-churchwill-look-different-after-covid/.

Sattler, Gary R. God's Glory, Neighbor's Good. Chicago, IL: Covenant Press, 1982.

Shantz, Douglas H. An Introduction to German Pietism: Protestant Renewal at the Dawn of Modern Europe, Baltimore, MD: The Johns Hopkins University Press, 2013.

Spener, Phillip Jacob. Pia Desideria, translated by Theodore G. Tappert. Minneapolis, MN: Fortress Press, 1964.

Stein, K. James. Phillip Jakob Spener: Pietist Patriarch. Chicago: Covenant Press, 1986.

Willimon, William H. Pastor: The Theology and Practice of Ordained Ministry. Nashville, TN: Abingdon Press, 2002.

Yeide Jr., Harry. Studies in Classical Pietism: The Flowering of The Ecclesiola. New York, NY: Peter Lang Publishing, 1997. 